\title{
Energy metabolism and ATP free-energy change of the intertidal worm Sipunculus nudus below a critical temperature
}

Accepted 4 July 1996

\begin{abstract}
The intertidal worm Sipunculus nudus was exposed to various temperatures for an analysis of the integrated changes in energy and acid-base status. Animals were incubated in sea water or maintained for up to 8 days at 4 and $0{ }^{\circ} \mathrm{C}$ while dwelling in the sediment. Cannulation of the animals prior to experimentation allowed the analysis of blood gas parameters $\left(P_{\mathrm{O}_{2}}\right.$, $P_{\mathrm{CO}_{2}}$ and $\left.\mathrm{pH}\right) . P_{\mathrm{O}_{2}}$ fell to 0 torr within 8 days at $0{ }^{\circ} \mathrm{C}$. A simultaneous reduction of ventilatory activity was derived from measurements of the pattern of coelomic fluid pressure changes associated with ventilatory movements. The increase in $P_{\mathrm{CO}_{2}}$ and an onset of anaerobic metabolism, indicated by the accumulation of end products like acetate and propionate both in the coelomic fluid and the body wall musculature, led to the development of a progressive acidosis and a deviation from the alphastat regulation of intracellular $\mathrm{pH}$ seen in unburied animals. The drop in intracellular $\mathrm{pH}$ together with the depletion of the adenylates and the phosphagen, phospho-L-arginine, reflect a significant decrease in the Gibb's free-energy change of ATP hydrolysis. These changes are interpreted to indicate lethal cold injuries, because recovery was not possible when the animals were returned to $12{ }^{\circ} \mathrm{C}$ after more than 2 days of exposure to $0^{\circ} \mathrm{C}$. A low critical temperature indicating the onset of cold-induced anaerobiosis is concluded to exist below $4{ }^{\circ} \mathrm{C}$ owing to the insufficient response of the ventilatory system to the developing hypoxia.
\end{abstract}

Key words Cold-induced anaerobiosis .

Acid-base status · Blood gas parameters .

S. Zielinski · H.O. Pörtner $(\square)$

Alfred-Wegener-Institut für Polar- und Meeresforschung, Biologie I/Ökophysiologie, Columbusstrasse, D-27568 Bremerhaven,

Germany

Tel.: + 49-471/4831-307, Fax: + 49-471/4831-149,

e-mail: hpoertner@awi-bremerhaven.de
Gibb's free-energy change of ATP hydrolysis . Intracellular $\mathrm{pH} \cdot \mathrm{Critical}$ temperature

Abbreviations $\Sigma$ Ade summed concentrations of ATP, ADP, AMP $\cdot \Sigma A r g$ summed concentrations of L-arginine containing metabolites $\cdot{ }_{L}$ - $A r g$ L-arginine $\cdot$ $d G / d \xi$ Gibb's free-energy change of ATP hydrolysis . $P C A$ perchloric acid $\cdot \mathrm{pH}_{e}$ extracellular $\mathrm{pH}$. $\mathrm{pH}_{i}$ intracellular $\mathrm{pH} \cdot P_{i}$ inorganic phosphate $P L A$ phospho-L-arginine $\cdot T_{C}$ critical temperature

\section{Introduction}

Intertidal animals like Sipunculus nudus are frequently subjected to temperature changes between tidal cycles, as well as to seasonal temperature fluctuations. For many invertebrates it has been shown that an increase in temperature leads to an increase in $\mathrm{O}_{2}$ consumption until a temperature threshold is surpassed, above which $\mathrm{O}_{2}$ consumption decreases (Newell and Pye 1970a, b; Kristensen 1983). Furthermore, temperature influences the ventilation rate. Baumfalk (1979) demonstrated for Arenicola marina that the pumping rate increases linearly with temperature between 5 and $22^{\circ} \mathrm{C}$ (for further examples see Discussion). However, some species inhabiting the intertidal zone may exhibit rates of physiological activity which are temperature independent (Newell and Pye 1970a,b). Some investigators looked at temperature-induced changes in biochemical tissue composition depending on the season. Zandee et al. (1980) for instance showed that the concentrations of proteins, glycogen and lipids in the muscles of Mytilus edulis rose in autumn. In winter at low temperatures these stores were broken down.

Temperature not only affects metabolism but also the acid-base status, usually in such a way that $\mathrm{pH}$ rises as temperature decreases. Reeves (1972) postulated that $\mathrm{pH}$ is not kept constant and independent of temperature but typically changes at $-0.017 \mathrm{pH}$ units per ${ }^{\circ} \mathrm{C}$ 
$(\Delta \mathrm{pH} / \Delta T)$ such that the dissociation of the histidine imidazole residues of proteins is kept constant (alphastat hypothesis). The constant degree of protonation will maintain the functional properties of a protein. This is supported by the finding that activities of several enzymes were almost unchanged when $\mathrm{pH}$ was increased according to alphastat during a temperature decrease, while a temperature drop at constant $\mathrm{pH}$ led to significant changes in enzyme activities (Hazel et al. 1978; Michaelidis and Storey 1990). As a corollary, pH regulation and metabolic regulation are interdependent processes.

The studies mentioned so far have not addressed the question of whether energy metabolism remains completely aerobic over the whole temperature range investigated. Murphy (1977) suggested for Modiolus demissus that anaerobic metabolism may become involved in energy production at low temperatures. His conclusion was based on the finding of elevated alanine and proline concentrations. Since proline is not an end product and alanine no major product of anaerobic metabolism the data are not sufficient for the conclusion that an onset of anaerobic metabolism occurs. Therefore, the present study was designed to investigate the influence of long-term exposure to low temperatures on metabolism and acid-base status of Sipunculus nudus. This worm irrigates its burrow by peristaltic waves of the body wall moving from head to tail, which induces a water current along the body surface (Pörtner 1982). Since the body of worms like Sipunculus nudus works as a hydraulic system, all movements are related to pressure changes in the coelomic fluid produced by the musculature (Zuckerkandl 1950; Trueman and FosterSmith 1976). When ventilation of Sipunculus nudus is reduced at low temperatures this might induce internal hypoxia. Particularly interesting was the question whether anaerobic metabolism truly becomes involved in energy production and how the temperature threshold for a potential transition to anaerobiosis is defined.

In many marine invertebrates opines are formed as end products of anaerobic glycolysis. During prolonged anaerobiosis glycolytic phophoenolpyruvate is converted into malate, which undergoes disproportionation in mitochondria and finally leads to the formation and accumulation of succinate, propionate and acetate (Grieshaber et al. 1994). The production of anaerobic metabolites would be advantageous for the animals at freezing temperatures, since Loomis et al. (1989) demonstrated that alanopine, strombine, propionate, acetate and lactate prevented the inactivation of lactate dehydrogenase and phosphofructokinase in a freeze-thaw cycle. This study also investigates whether the energy status, quantified as the Gibb's free-energy change of ATP hydrolysis $(\mathrm{d} G / \mathrm{d} \xi)$, can be maintained under these conditions or whether this parameter can be used as an indicator of low temperature stress.

\section{Materials and methods}

\section{Animals}

Specimens of Sipunculus nudus from the intertidal flats near Morgat (small animals of 4.1-11.4 g) and Locquemeau (large animals of 28.5-55.1 g) were provided in February 1994 by the Biological station of Roscoff, Brittany, France. In Bremerhaven the animals were kept in tanks with a bottom layer of sand $(10-20 \mathrm{~cm})$ and recirculated natural sea water at $12 \pm 1{ }^{\circ} \mathrm{C}$.

\section{Experimental procedures}

All incubations were carried out in darkened aquaria containing 151 of aerated natural sea water. The aquaria were placed in a water bath thermostatted to the experimental temperature.

Large specimens of Sipunculus nudus were incubated for $24 \mathrm{~h}$ at 0 , $5,10,15,20$ and $25^{\circ} \mathrm{C}$. The animals were directly transferred to water of 5,10 and $15^{\circ} \mathrm{C}$. For the incubation at $0{ }^{\circ} \mathrm{C}$ they were transferred to water of $5^{\circ} \mathrm{C}$ which was cooled to $0^{\circ} \mathrm{C}$ within $14 \mathrm{~h}$. Incubations at 20 and $25^{\circ} \mathrm{C}$ started at a water temperature of $15^{\circ} \mathrm{C}$ and the experimental temperatures were reached after 7 and $7.5 \mathrm{~h}$, respectively.

In a second set of experiments a bottom layer of sand $(10 \mathrm{~cm})$ was added to the aquaria. Large specimens were catheterized using the technique described by Pörtner et al. (1986). The animals were then allowed to dig into the sand at a water temperature of $12^{\circ} \mathrm{C}$. After $24 \mathrm{~h}$ the temperature was decreased and the animals were incubated for another 8 days. One group of animals was exposed to $0{ }^{\circ} \mathrm{C}$, another to $4{ }^{\circ} \mathrm{C}$. These temperatures were reached after 9 and $7 \mathrm{~h}$, respectively. The third group was incubated for 4 days at $0{ }^{\circ} \mathrm{C}$; after this time the temperature was increased within $10 \mathrm{~h}$ and maintained at $12{ }^{\circ} \mathrm{C}$ for another 4 days. Owing to repeated sampling of coelomic fluid these animals were sacrificed only at the end of the experimental period.

One animal of each group was connected to a pressure transducer (UFI Type 1050, Morro Bay, Calif. USA) via the indwelling catheter. Ventilatory body movements associated with pressure fluctuations in the coelomic fluid were monitored using a MacLab system (ADI Instruments, Hastings, UK).

Small specimens were allowed to dig into the sand at a water temperature of $12{ }^{\circ} \mathrm{C}$. After $24 \mathrm{~h}$ the temperature was decreased to $0{ }^{\circ} \mathrm{C}$. A group of ten animals was incubated at $0{ }^{\circ} \mathrm{C}$ for 2 days, when five animals were removed and the temperature was returned to $12^{\circ} \mathrm{C}$. The remaining five animals were kept at this temperature for another 3 days. A second group was incubated for 4 days at $0{ }^{\circ} \mathrm{C}$. After removing five animals, the temperature was increased to $12^{\circ} \mathrm{C}$ and the remaining animals removed after 3 days. Another five animals were directly taken from the aquarium tank as control animals. All temperatures $\pm 0.5^{\circ} \mathrm{C}$.

Analyses

Coelomic fluid samples were withdrawn once every day via the indwelling catheter and analyzed for extracellular $\mathrm{pH}\left(\mathrm{pH}_{\mathrm{e}}\right), P_{\mathrm{O}_{2}}$ and $P_{\mathrm{CO}_{2}}$ using Eschweiler (Kiel, Germany) equipment (MT3R-monitor and electrodes, thermostatted to the incubation temperature of the animals). The electrodes were calibrated with precision buffers (Radiometer, Copenhagen, Denmark) or humidified calibration gases prepared from pure $\mathrm{N}_{2}, \mathrm{CO}_{2}$ and $\mathrm{CO}_{2}$-free air by gas-mixing pumps (type 2M303/a-F, Wösthoff, Bochum, Germany).

At the end of each experiment the animals were dissected quickly in the dorsoventral plane. Body wall tissue was freeze clamped, wrapped in aluminium foil and stored under liquid $\mathrm{N}_{2}$ until analyzed. Intracellular $\mathrm{pH}$ was determined using the homogenate 
technique described by Pörtner et al. (1990). After grinding the tissue under liquid $\mathrm{N}_{2}$ and transfer of the tissue powder into closed Eppendorf caps containing $250 \mu \mathrm{l}$ of $160 \mathrm{mmoll}^{-1} \mathrm{KF}$ and $0.5 \mathrm{mmol}^{-1}$ nitrilotriacetic acid, the Eppendorf caps were filled with medium, closed and treated with ultrasound for $2 \mathrm{~min}$. During this period samples were kept cold at a temperature below $-6{ }^{\circ} \mathrm{C}$ in a mixture of ice and salt.

The remaining tissue powder was extracted in PCA following the procedure of Beis and Newsholme (1975), modified according to Pette and Reichmann (1982). Coelomic plasma, which was obtained after centrifugation of coelomic fluid (for $4 \mathrm{~min}$ at $14000 \mathrm{~g}$ ), was extracted according to Pörtner et al. (1984).

The following metabolites were determined enzymatically in the body wall musculature: ATP, ADP, AMP and succinate (Bergmeyer et al. 1989), $P_{i}$ (Pörtner 1990), PLA, L-Arg and octopine (Grieshaber et al. 1978). The concentrations of acetate, propionate, strombine and alanopine were analysed with a Dionex BioLC ion chromatograph (Idstein, Germany). The measurement of acetate and propionate followed a procedure modified after Hardewig et al. (1991), using $0.125 \mathrm{mmol}^{-1}$ octane sulphonic acid as an eluent. The column was thermostatted to $40^{\circ} \mathrm{C}$. Separation of strombine and alanopine was performed with a Dionex RT 100-6,5 Polyspher ARAC column, using $5 \cdot 10^{-5} \mathrm{moll}^{-1} \mathrm{HCl}$ as an eluent with a flow rate of $0.6 \mathrm{ml} \mathrm{min}{ }^{-1}$. The column was thermostatted to $45^{\circ} \mathrm{C}$. Peaks were monitored with a conductivity detector. Standard opine solution for calibration was prepared by means of in vitro synthesis (Siegmund and Grieshaber 1983). IMP levels were measured in PCA extracts with a Pharmacia HPLC (Uppsala, Sweden) after Tekkanat and Fox (1988) using $0.55 \mathrm{moll}^{-1}$ acetonitrile, $0.06 \mathrm{moll}^{-1} \mathrm{KH}_{2} \mathrm{PO}_{4}$ and $0.45 \mathrm{mmoll}^{-1}$ tetrabutylammoniumdihydrogenphosphate as an eluent ( $\mathrm{pH} 4.85$ ) to which $8 \%$ methanol was added.

The levels of free ADP and AMP and $\mathrm{d} G / \mathrm{d} \xi$ were calculated based on the equilibrium of arginine kinase and myokinase. Equilibrium constants for both enzymes were corrected for experimental temperature and $\mathrm{pH}$ dependence as related to changing proton and magnesium binding of the adenylates and the proton turnover of the arginine kinase reaction (Pörtner 1993; Pörtner et al. 1996).

The significance of changes in extracellular $\mathrm{pH}, P_{\mathrm{O}_{2}}$ and $P_{\mathrm{CO}_{2}}$, intracellular $\mathrm{pH}$ and in the concentrations of metabolites was tested at the $5 \%$ level by one-way analysis of variance (ANOVA) and Student-Newman-Keuls posthoc tests as well as Student's $t$-test for unpaired samples.

\section{Results}

Incubation of Sipunculus nudus at low temperatures (4 and $0{ }^{\circ} \mathrm{C}$ ) in sand led to the sedimentation of coelomic cells, indicated by a change of the coelomic fluid samples to a clear solution on the second day. No significant changes in coelomic gas parameters and volatile fatty acid concentrations were seen at $4{ }^{\circ} \mathrm{C}$. A trend for $P_{\mathrm{O}_{2}}$ and $\mathrm{pH}_{\mathrm{e}}$ to decrease was observed between day 5 and day 7 , at the same time the highest acetate concentrations were found. $\mathrm{PCO}_{2}$ values fluctuated between $2.6 \pm 0.8 \mathrm{~mm} \mathrm{Hg}$ on day 1 and $3.5 \pm 0.6 \mathrm{~mm} \mathrm{Hg}$ after 7 days. $\mathrm{pH}, P_{\mathrm{CO}_{2}}$ and propionate levels were not significantly different owing to high inter-individual variability.

Lowering temperature to $0^{\circ} \mathrm{C}$ (Fig. 1) resulted in a significant decrease in $\mathrm{P}_{\mathrm{O}_{2}}$ from day 7 until on the last day when $\mathrm{O}_{2}$ was no longer detectable. $P_{\mathrm{CO}_{2}}$ and propionate levels rose at the same time. The concentration of acetate increased to a maximum of $0.64 \pm 0.34 \mathrm{mmoll}^{-1}$ coelomic fluid on the last day.
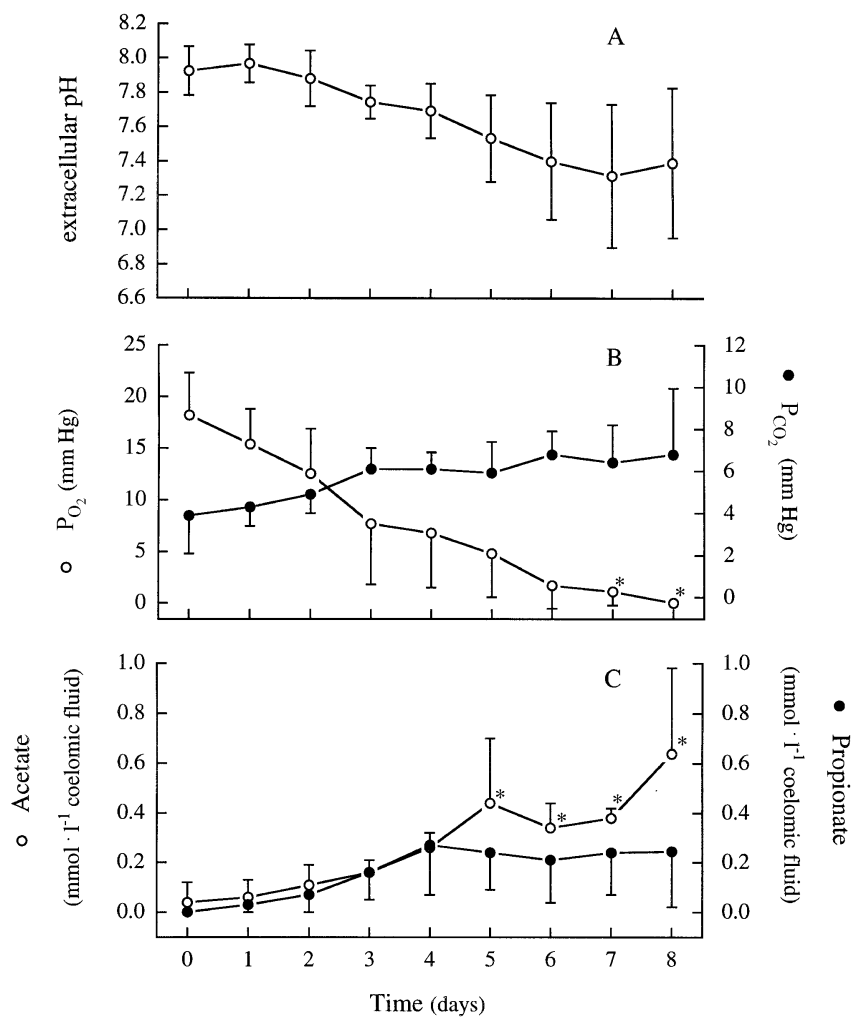

Fig. 1A-C Extracellular pH, oxygen and $\mathrm{CO}_{2}$ partial pressures, and the concentrations of acetate and propionate in the coelomic fluid of Sipunculus nudus (large animals) dwelling in sediment. After $24 \mathrm{~h}$ ( = day 1) the incubation temperature was lowered from 12 to $0^{\circ} \mathrm{C}$ within $9 \mathrm{~h}$ (* significantly different from controls; day $0-7: n=5$; day $8: n=3$ )

The values from days 5-8 were significantly different from the concentrations found at $12{ }^{\circ} \mathrm{C}$.

Similar results were obtained in a second experiment when the temperature was first lowered to $0{ }^{\circ} \mathrm{C}$ and after day 4 raised to $12^{\circ} \mathrm{C}$ again (Fig. 2). Within 8 days coelomic $P_{\mathrm{O}_{2}}$ decreased significantly to $0 \mathrm{~mm} \mathrm{Hg}$ and $\mathrm{pH}_{\mathrm{e}}$ fell to $\mathrm{pH} 6.68 \pm 0.09 . P_{\mathrm{CO}_{2}}$ increased significantly from $3.0 \pm 0.4$ to $15.8 \pm 2.0 \mathrm{~mm} \mathrm{Hg}$. Concentrations of acetate and propionate also rose to maximum values of $6.66 \pm 3.59 \mathrm{mmol}^{-1}$ coelomic fluid and $0.32 \pm 0.24 \mathrm{mmol}^{-1}$ coelomic fluid, respectively.

All animals incubated at $0{ }^{\circ} \mathrm{C}$ were in a very poor condition at the end of the experiments. One of those large animals, which was rewarmed to $12{ }^{\circ} \mathrm{C}$ after 4 days at $0{ }^{\circ} \mathrm{C}$ and two of those large animals, which were exposed to $0^{\circ} \mathrm{C}$ for 8 days, died (no longer included in data set).

The recording of pressure changes in the coelomic fluid revealed ventilatory movements typical for animals which had constructed a burrow in the sediment (Fig. 3A). At $12{ }^{\circ} \mathrm{C}$ individual, larger peaks associated with digging movements were recorded at irregular intervals. These digging movements ceased when the temperature was lowered to 4 and $0{ }^{\circ} \mathrm{C}$. At $4{ }^{\circ} \mathrm{C}$ ventilatory movements were observed at mean values of $0.03 \mathrm{~Hz}$ 

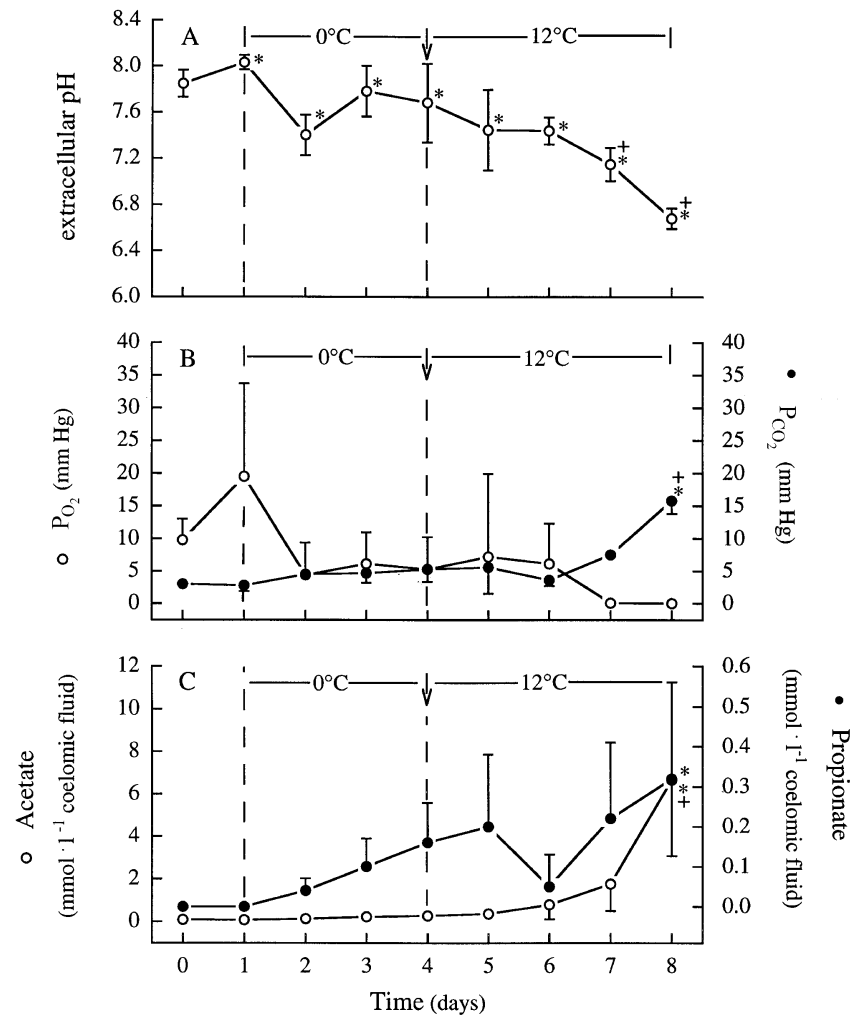

Fig. 2A-C Extracellular $\mathrm{pH}$, oxygen and $\mathrm{CO}_{2}$ partial pressures, and the concentrations of acetate and propionate in the coelomic fluid of Sipunculus nudus (large animals) during incubation in sediment. Initially, the temperature was lowered from 12 to $0{ }^{\circ} \mathrm{C}$ within $9 \mathrm{~h}$. After 4 days the animals were warmed to $12{ }^{\circ} \mathrm{C}$ within $12 \mathrm{~h}$ ( * significantly different from controls, + significantly different from the values after 4 days at $0{ }^{\circ} \mathrm{C}$; day $0-5: n=4$; day 6-8: $n=3$ )
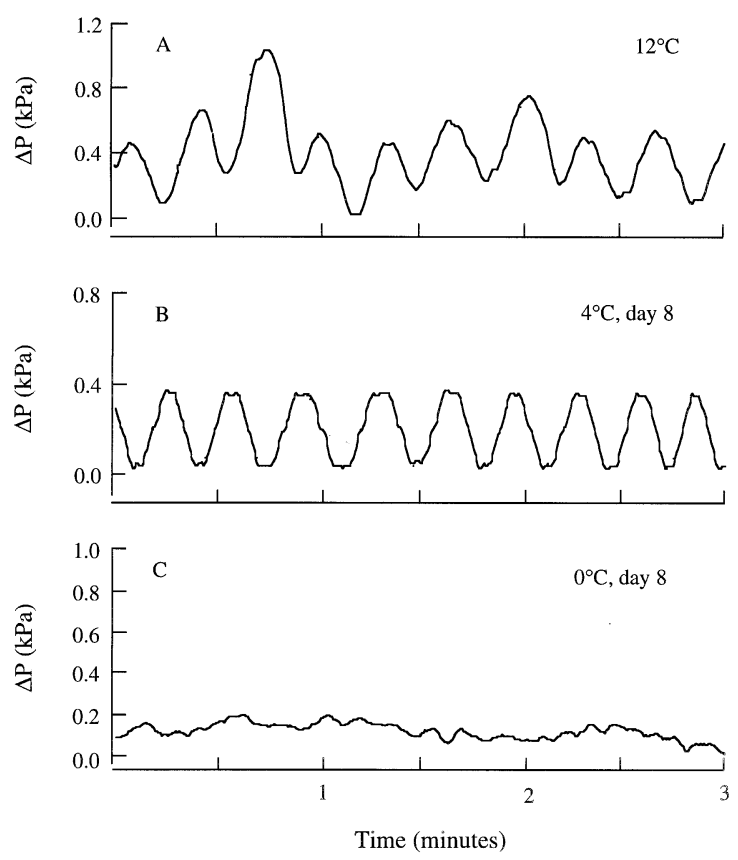

Fig. 3A-C Ventilatory activities of Sipunculus nudus (large animal) burrowed in the sediment at $12{ }^{\circ} \mathrm{C}(\mathbf{A}), 4{ }^{\circ} \mathrm{C}(\mathbf{B})$ and at $0{ }^{\circ} \mathrm{C}(\mathbf{C})$. $(n=1)$
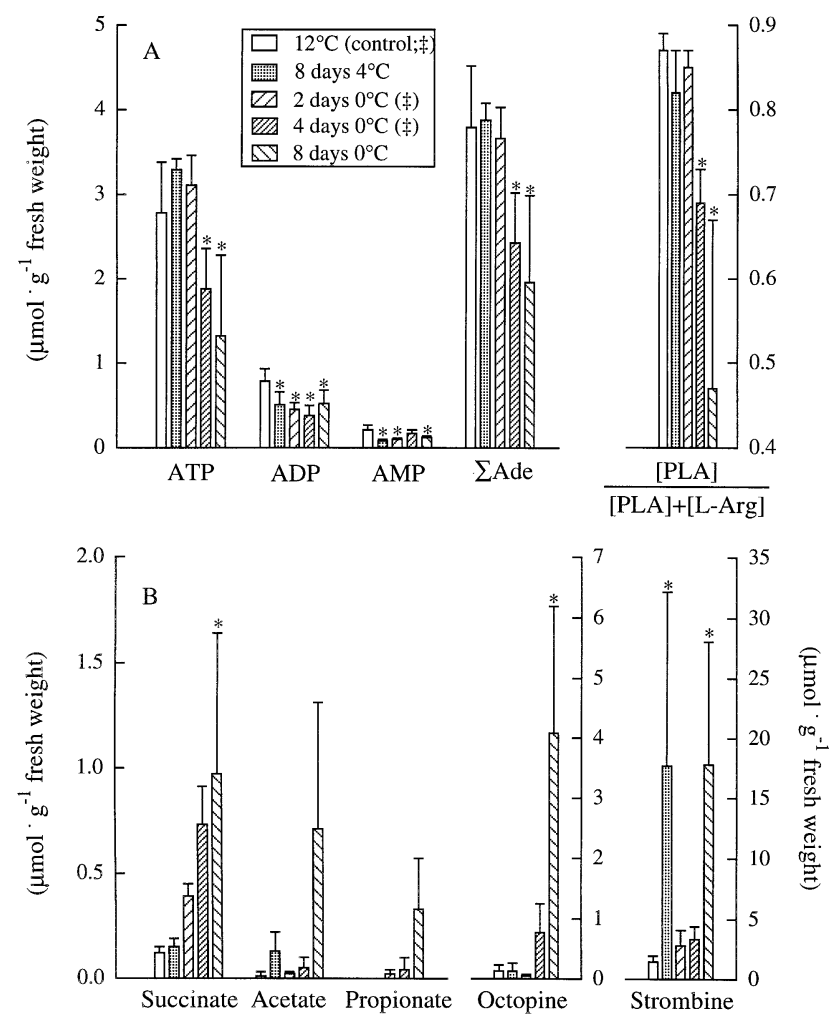

Fig. 4A, B Concentrations of ATP, ADP, AMP and $\Sigma$ Ade, the ratio of the levels of phospho-L-arginine over the sum of the concentrations of PLA and L-arginine (A) and the levels of succinate, acetate, propionate, octopine and strombine $(\mathbf{B})$ in the body wall musculature of Sipunculus nudus (large and small animals) during exposure to $0{ }^{\circ} \mathrm{C}$ in the sediment (* significantly different from controls; $n=5$, except after 8 days at $0{ }^{\circ} \mathrm{C}: n=3 ;{ }^{\ddagger}$ indicates data collected from small animals)

and $0.6 \mathrm{kPa}$ during the whole experimental period. At $0{ }^{\circ} \mathrm{C}$, the ventilation frequency decreased from $0.03 \mathrm{~Hz}$ at $12{ }^{\circ} \mathrm{C}$ to $0.01 \mathrm{~Hz}$ within 8 days and the amplitude fell from $0.7 \mathrm{kPa}$ at $12^{\circ} \mathrm{C}$ to $0.2 \mathrm{kPa}$ during this period. Towards the end of the experiments ventilatory activity was no longer visible (Fig. 3).

In the body wall musculature the concentrations of the adenylates ATP and ADP and the summed contents of ATP, ADP and AMP ( $\Sigma$ Ade) decreased during exposure to $0{ }^{\circ} \mathrm{C}$ (Fig. 4a), while the concentration of $\mathrm{P}_{\mathrm{i}}$ rose (Table 1). The depletion of ATP did not lead to elevated AMP levels, but rather to a significant decrease after exposure to 4 and $0{ }^{\circ} \mathrm{C}$ (for 2 and 8 days). At the same time the concentrations of IMP rose reaching significantly higher levels during exposure to $0{ }^{\circ} \mathrm{C}$ for 8 days and during rewarming to $12^{\circ} \mathrm{C}$ after 4 days at $0{ }^{\circ} \mathrm{C}$ (Table 1). Furthermore, the concentrations of the phosphagen PLA fell, while arginine levels rose leading to a significantly reduced $\Sigma A$ Arg and a drop of the ratio of PLA over L-Arg plus PLA concentrations after 8 days at $0{ }^{\circ} \mathrm{C}$ (Table 1, Fig. 4A). Data from small and large animals were combined in Figs. 4, 7 and Table 1 since a comparison of metabolite levels under 
Table 1 Concentrations ( $\mu \mathrm{mol} \mathrm{g}{ }^{-1}$ fresh weight) of inorganic phosphate, IMP, phospho-L-arginine, L-arginine and the summed levels of L-arginine containing metabolites $(\Sigma \mathrm{Arg}=[\mathrm{PLA}]+[\mathrm{L}-$ Arg $]+[$ Octopine $]$ ) in the body wall musculature of Sipunculus nudus (large and small animals) after exposure to $4{ }^{\circ} \mathrm{C}$ and $0{ }^{\circ} \mathrm{C}$ for up to 8 days in sediment, and after rewarming to $12^{\circ} \mathrm{C}$ after different periods at $0{ }^{\circ} \mathrm{C}$. Values are means $\pm \mathrm{SD}$

\begin{tabular}{|c|c|c|c|c|c|c|}
\hline $\begin{array}{l}\text { Temperature } \\
\left({ }^{\circ} \mathrm{C}\right)\end{array}$ & $\begin{array}{l}\text { Time } \\
\text { (days) }\end{array}$ & PLA & L-Arg & $\Sigma$ Arg & $P_{i}$ & IMP \\
\hline 12 (control) & & $45.03 \pm 4.42$ & $6.66 \pm 0.85$ & $52.12 \pm 4.77$ & $2.92 \pm 1.34$ & $0.03 \pm 0.02$ \\
\hline 4 & 8 & $33.69 \pm 4.11^{\mathrm{a}}$ & $7.22 \pm 1.99$ & $41.02 \pm 3.56$ & $2.55 \pm 1.80$ & $0.04 \pm 0.01$ \\
\hline 0 & $2^{\mathrm{b}}$ & $46.66 \pm 3.48$ & $8.58 \pm 1.04$ & $55.29 \pm 3.96$ & $4.02 \pm 1.32$ & $0.04 \pm 0.02$ \\
\hline 0 & $4^{\mathrm{b}}$ & $29.15 \pm 5.62^{\mathrm{a}}$ & $12.95 \pm 1.69^{\mathrm{a}}$ & $42.87 \pm 6.85$ & $8.86 \pm 3.69$ & $0.03 \pm 0.02$ \\
\hline 0 & 8 & $15.40 \pm 10.84^{\mathrm{a}}$ & $13.91 \pm 1.73^{\mathrm{a}}$ & $33.39 \pm 9.61^{\mathrm{a}}$ & $9.74 \pm 2.48$ & $0.15 \pm 0.02^{\mathrm{a}}$ \\
\hline 12 (after 2 days at $0^{\circ} \mathrm{C}$ ) & $3^{\mathrm{b}}$ & $45.01 \pm 7.04$ & $7.90 \pm 2.23$ & $53.06 \pm 5.58$ & $3.02 \pm 1.03$ & $0.04 \pm 0.01$ \\
\hline 12 (after 4 days at $0^{\circ} \mathrm{C}$ ) & $3^{\mathrm{b}}$ & $7.84 \pm 3.10^{\mathrm{a}}$ & $26.34 \pm 3.98^{\mathrm{a}}$ & $29.97 \pm 11.39^{\mathrm{a}}$ & $13.31 \pm 6.85^{\mathrm{a}}$ & $0.29 \pm 0.13^{\mathrm{a}}$ \\
\hline
\end{tabular}

${ }^{\text {a }}$ Significantly different from controls

${ }^{\mathrm{b}}$ Data collected from small animals

Table 2 Intracellular $\mathrm{pH}$, the ratio of the levels of phospho-L-arginine over the sum of the concentrations of PLA and L-arginine and the concentrations ( $\mu \mathrm{mol} \mathrm{g}^{-1}$ fresh weight) of octopine, ATP, ADP, AMP, the summed concentrations of the adenylates and the levels of acetate, propionate and strombine in the body wall musculature of Sipunculus nudus (large animals) after $24 \mathrm{~h}$ of incubation in cold sea water without sediment ( ${ }^{\mathrm{a}}$ significantly different from control values; 0,5 and $10^{\circ} \mathrm{C}: n=6 ; 15,20$ and $25^{\circ} \mathrm{C}: n=5$ )

\begin{tabular}{|c|c|c|c|c|c|c|}
\hline & $0^{\circ} \mathrm{C}$ & $5^{\circ} \mathrm{C}$ & $10^{\circ} \mathrm{C}$ & $15^{\circ} \mathrm{C}$ & $20^{\circ} \mathrm{C}$ & $25^{\circ} \mathrm{C}$ \\
\hline $\mathrm{pHi}$ & $7.45 \pm 0.01$ & $7.42 \pm 0.01$ & $7.30 \pm 0.02$ & $7.25 \pm 0.01$ & $7.20 \pm 0.02$ & $7.07 \pm 0.03$ \\
\hline $\begin{array}{l}{[\mathrm{PLA}] /} \\
{[\mathrm{PLA}]+[\mathrm{L}-\mathrm{Arg}]}\end{array}$ & $0.93 \pm 0.01$ & & & $0.92 \pm 0.01$ & & $0.93 \pm 0.01$ \\
\hline Octopine & $0.01 \pm 0.01$ & $0.01 \pm 0.00$ & $0.01 \pm 0.01$ & $0.01 \pm 0.01$ & $0.02 \pm 0.01$ & $0.03 \pm 0.01$ \\
\hline ATP & $3.23 \pm 0.53$ & & & $3.28 \pm 0.45$ & & $3.71 \pm 0.33$ \\
\hline ADP & $0.42 \pm 0.06$ & $0.47 \pm 0.08$ & $0.38 \pm 0.04$ & $0.36 \pm 0.11$ & $0.39 \pm 0.13$ & $0.40 \pm 0.08$ \\
\hline AMP & $0.08 \pm 0.03$ & $0.08 \pm 0.03$ & $0.07 \pm 0.01$ & $0.07 \pm 0.01$ & $0.09 \pm 0.04$ & $0.08 \pm 0.01$ \\
\hline$\Sigma$ [Adenylate] & $3.77 \pm 0.63$ & & & $3.71 \pm 0.52$ & & $4.19 \pm 0.37$ \\
\hline $\mathrm{Pi}$ & $0.68 \pm 0.48$ & $0.67 \pm 0.41$ & $1.53 \pm 0.66$ & $0.73 \pm 0.68$ & $0.66 \pm 0.68$ & $1.17 \pm 0.53$ \\
\hline Acetate & $0.00 \pm 0.00$ & & & $0.02 \pm 0.04$ & & $0.01 \pm 0.03$ \\
\hline Propionate & $0.04 \pm 0.06$ & & & $0.14 \pm 0.05$ & & $0.02 \pm 0.03^{\mathrm{a}}$ \\
\hline Strombine & $0.84 \pm 0.04$ & & & $0.85 \pm 0.42$ & & $0.51 \pm 0.31$ \\
\hline
\end{tabular}

control conditions and after 4 days at $0{ }^{\circ} \mathrm{C}$ and 3 days of subsequent warming at $12^{\circ} \mathrm{C}$ revealed no significant difference between small and large specimens and led to the conclusion that small and large animals are equally sensitive to temperature change.

Depending upon the length of the incubation period, keeping the animals at $0{ }^{\circ} \mathrm{C}$ caused a rise in the concentrations of succinate, of the volatile fatty acids acetate and propionate and of the opine strombine in the body wall (Fig. 4B). None of these changes were observed in the unburied animals exposed to $0^{\circ} \mathrm{C}$ for $24 \mathrm{~h}$ (Table 2).

Recovery of small animals at $12{ }^{\circ} \mathrm{C}$ was only possible when exposure to $0{ }^{\circ} \mathrm{C}$ did not exceed 2 days. Under these conditions the concentrations of ADP and AMP decreased during low temperature exposure but the ADP level returned to control values after returning the animals to $12^{\circ} \mathrm{C}$ (Fig. 5A). Warming after 4 days at $0{ }^{\circ} \mathrm{C}$ resulted in further depletion of these metabolites and of the phosphagen PLA (Fig. 5B, Table 1). Concentration changes of anaerobic end products confirmed the observation that the ability to recover depended upon the length of the incubation period. While exposure to $0{ }^{\circ} \mathrm{C}$ caused the levels of succinate, acetate, propionate, octopine and strombine to rise, this trend was reversed during rewarming after 2 days of cold exposure, but not during rewarming after exposure to $0{ }^{\circ} \mathrm{C}$ for 4 days (Fig. 6).

Incubation of unburied animals between 0 and $25^{\circ} \mathrm{C}$ led to a decrease of $\mathrm{pH}_{\mathrm{i}}$ with increasing temperature (Table 2), following a slope of $-0.015 \mathrm{pH}$ units per ${ }^{\circ} \mathrm{C}$. Similar slopes were seen for the $\mathrm{pH}_{\mathrm{i}}$ of animals incubated in sand at $4{ }^{\circ} \mathrm{C}$ and for 2 days at $0{ }^{\circ} \mathrm{C}$ with -0.014 or $-0.012 \mathrm{pH}$ units per ${ }^{\circ} \mathrm{C}$, respectively, leading to a significant rise in $\mathrm{pH}_{\mathrm{i}}$ above the control value of $\mathrm{pH} 7.29 \pm 0.03$ (Fig. 7A). This $\mathrm{pH}$ was restored when the animals were brought back to $12^{\circ} \mathrm{C}$ after 2 days at $0{ }^{\circ} \mathrm{C}$. Eight days at $0{ }^{\circ} \mathrm{C}$ and rewarming the animals after 4 days at $0^{\circ} \mathrm{C}$ resulted in the development of an uncompensated acidosis. This acidosis together with the accumulation of $\mathrm{P}_{\mathrm{i}}$ and the depletion of the adenylates led to a significant drop in $\mathrm{d} G / \mathrm{d} \xi_{\mathrm{ATP}}$ from $-56.1 \pm 1.5 \mathrm{~kJ} \mathrm{~mol}^{-1}$ (control animals) to a minimum value of $-45.5 \pm 0.8 \mathrm{~kJ} \mathrm{~mol}^{-1}$ (Fig. 7B, C) in those animals which had been rewarmed after 4 days at $0{ }^{\circ} \mathrm{C}$. The levels of free AMP and ADP also rose when animals were rewarmed after 4 days but not in those rewarmed after 2 days of exposure to $0{ }^{\circ} \mathrm{C}$. 

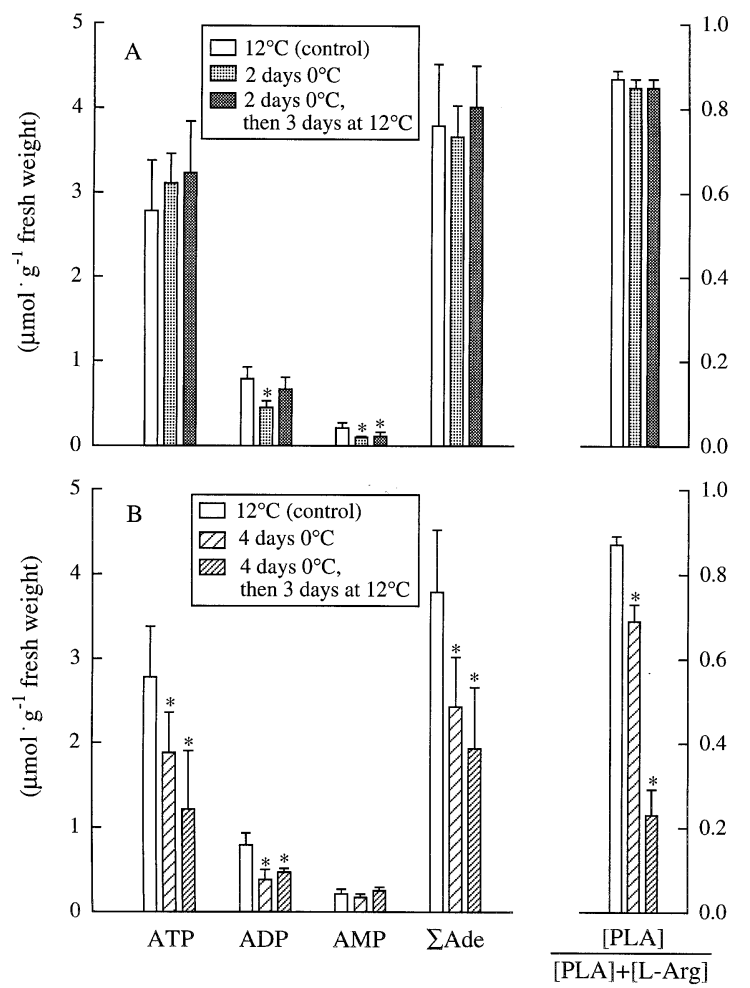

Fig. 5A, B Effect of rewarming of Sipunculus nudus (small animals) after 2 days (A) and 4 days (B) of exposure to $0{ }^{\circ} \mathrm{C}$ in sediment on the concentrations of ATP, ADP, ANP, $\Sigma$ Ade and the ratio of the levels of PLA over the sum of the concentrations of PLA and L-Arg (* significantly different from controls; $n=5$, except 2 days $0{ }^{\circ} \mathrm{C}$, then 3 days at $12^{\circ} \mathrm{C}: n=4$ )

\section{Discussion}

\section{Cold-induced anaerobiosis}

The incubation of Sipunculus nudus in sand at low temperatures caused the production of anaerobic metabolites. The onset of anaerobic metabolism is correlated with the decrease in $\mathrm{O}_{2}$ partial pressure in the coelomic fluid. Pörtner et al. (1985) demonstrated that $24 \mathrm{~h}$ of incubation at low $\mathrm{O}_{2}$ tensions between 15 and $7.5 \mathrm{~mm} \mathrm{Hg}$ in the ambient water, which corresponds to a $P_{\mathrm{O}_{2}}$ below $4 \mathrm{~mm} \mathrm{Hg}$ in the coelomic fluid, led to an accumulation of anaerobic products like succinate, propionate and acetate. In the present experiments the concentrations of anaerobic metabolites actually increased significantly when $\mathrm{O}_{2}$ partial pressures in the coelomic fluid fell below about $5 \mathrm{~mm} \mathrm{Hg}$. Insufficient provision of $\mathrm{O}_{2}$ at low temperature is therefore concluded to elicit the onset of anaerobic metabolism.

The drop in coelomic fluid $P_{\mathrm{O}_{2}}$ was probably caused by the reduction and finally elimination of ventilatory activity during low temperature exposure. A strong influence of temperature on ventilatory activity of marine invertebrates has already been reported for other species. Theede (1972) showed that the movements of cilia in isolated gills of the mussel Spisula solida slowed
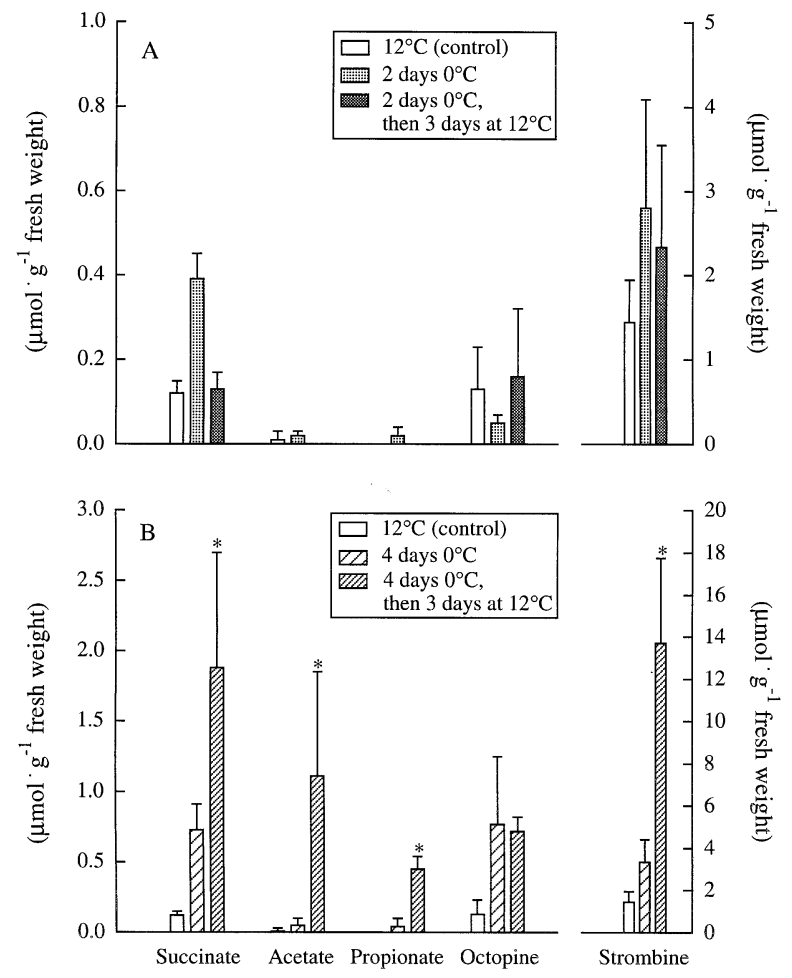

Fig. 6A, B Effect of rewarming of Sipunculus nudus (small animals) after 2 days (A) and 4 days (B) of exposure to $0{ }^{\circ} \mathrm{C}$ in sediment on the concentrations of succinate, acetate, propionate, octopine and strombine (*significantly different from controls; $n=5$ except 2 days $0{ }^{\circ} \mathrm{C}$, then 3 days at $12^{\circ} \mathrm{C}: n=4$ )

down drastically at temperatures below $5^{\circ} \mathrm{C}$. Measurements of the ventilation rate of three species of the polychaete Nereis revealed that the rate decreased below $25^{\circ} \mathrm{C}$ and finally reached very low values (Kristensen 1983). We conclude that an insufficiency of ventilatory mechanisms develops at low temperature which causes inadequate $\mathrm{O}_{2}$ supply and the transition to anaerobiosis. This conclusion is supported by the observation that coelomic cells sediment at low temperature reflecting insufficient suspension of the cells by peristaltic movements of the body wall. For comparison, Sipunculus nudus incubated in cold sea water without sediment did not switch to anaerobiosis within $24 \mathrm{~h}$ (Table 2), whereas Arenicola marina did (Sommer et al. 1996). Arenicola possesses a circulatory system, the pulsation frequency of which is reduced at low temperatures (Seymour 1972). Sipunculus possesses no circulatory system emphasizing that insufficient ventilation and mixture of body fluids go hand in hand below the critical temperature.

In the present study, the production rate of anaerobic metabolites was reduced compared to $24 \mathrm{~h}$ of experimental anaerobiosis at $15^{\circ} \mathrm{C}$ (Pörtner et al. 1984). Further comparison reveals that more propionate than acetate is produced at high temperatures, whereas acetate reached higher levels than propionate at low temperature. It is completely unknown whether 

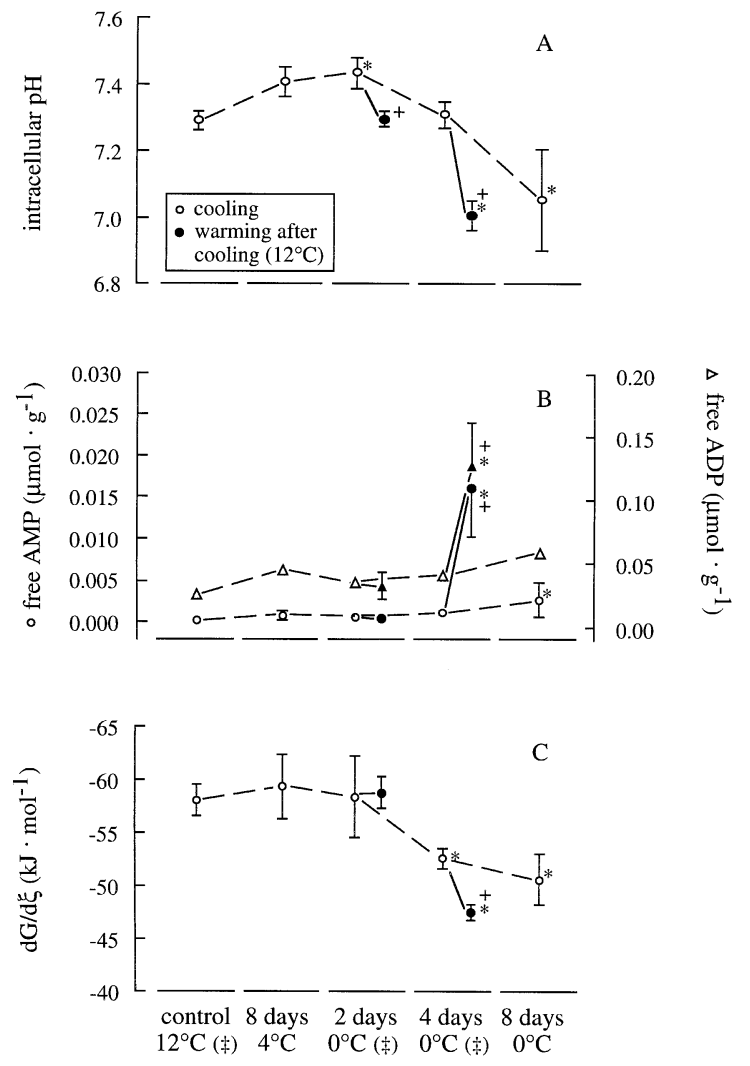

Fig. 7A-C Intracellular $\mathrm{pH}(\mathbf{A})$ in the body wall musculature of Sipunculus nudus [large and small $\left({ }^{\ddagger}\right)$ animals] after exposure to $4{ }^{\circ} \mathrm{C}$ and $0^{\circ} \mathrm{C}$ and after rewarming to $12^{\circ} \mathrm{C}$, as well as the levels of free AMP and ADP (B) and the free-energy change of ATP hydrolysis (C)

propionate synthesis is more temperature sensitive than acetate. During anaerobic propionate formation, the rate-limiting step is the decarboxylation of methylmalonyl-CoA by the propionyl-CoA carboxylase which releases bicarbonate. Kinetic measurements in purified enzyme preparations of propionyl-CoA carboxylase from the body wall musculature of Arenicola marina showed that a non-respiratory acidosis (low bicabonate levels) enhances the rate of decarboxylation. Measurements at a contant $\mathrm{pH}$ of 7.0 revealed that $\mathrm{HCO}_{3}^{-}$has an inhibitory effect (Hardewig et al. 1994). Exposure of Sipunculus nudus in sand at low temperatures caused a rise in $\mathrm{pH}$ and most likely bicarbonate levels, thereby possibly impeding propionate production and favouring acetate formation. Activities of enzymes involved in acetate formation may be less affected by the temperature decrease than enzymes of the propionate pathway, but more data are needed before more definite conclusions can be drawn.

\section{Adenylate catabolism}

Energy turnover during anaerobiosis is reduced in comparison to aerobic metabolism (Zebe et al. 1980) which is also the case in Sipunculus nudus (Hardewig et al. 1991). During $24 \mathrm{~h}$ of anaerobiosis at constant temperature in open sea water adenylate concentrations did not change significantly in the body wall, since ATP levels were buffered at the expense of PLA (Pörtner et al. 1984; Pörtner 1987b). However, long term incubation of Sipunculus nudus in the sediment caused a reduction in both PLA and ATP concentrations after 4 and 8 days at $0^{\circ} \mathrm{C}$ (Fig. 4A). ATP depletion can occur due to an enhanced utilisation and/or a reduced production rate. The latter could be caused by a decrease in glycolytic rate due to the fact that polymeric enzymes dissociate into subunits at low temperatures as has been shown for the tetrameric glucose-6-phosphate dehydrogenase and phosphofructokinase (Prosser 1991). However, ATP depletion was not associated with an accumulation of AMP, but AMP levels fell instead, together with a decrease in the summed levels of the adenylates. This implies that a degradation beyond AMP occurred, possibly caused by a temperature-dependent shift in the reaction equilibrium of the deamination of AMP to IMP by AMP deaminase. This is suggested by the decrease in AMP and rise in IMP levels at $4{ }^{\circ} \mathrm{C}$ when $[\mathrm{ATP}]$ is still constant. The temperature decrease possibly favoured the breakdown of adenylates, starting with AMP and subsequently causing the decrease of the other adenylates through the equilibrium of the adenylate kinase, the temperature dependence of which is known to be very small (Tewari et al. 1991).

\section{Acid-base regulation and ATP free-energy change}

During long-term incubation at $4{ }^{\circ} \mathrm{C}$ and during 2 days at $0{ }^{\circ} \mathrm{C}$ the $\mathrm{pH}_{\mathrm{i}}$ of Sipunculus nudus changed according to the alphastat hypothesis. In this respect, Sipunculus nudus behaves like many other animals. Howell et al. (1970) determined a slope of $-0.016 \mathrm{pH}$ units per ${ }^{\circ} \mathrm{C}$ in the arterial blood of the frog Rana catesbeiana and the toad Bufo marinus for the temperature range 5-37 ${ }^{\circ} \mathrm{C}$. For Rana catesbeiana musculature $\Delta \mathrm{pH} / \Delta T$ was -0.015 between $5{ }^{\circ} \mathrm{C}$ and $30^{\circ} \mathrm{C}$ (Malan et al. 1976). Other authors demonstrated that there can be differences between intra- and extracellular compartments. The $\mathrm{pH}$ in the blood of Salmo trutta followed alphastat regulation, whereas $\mathrm{pH}_{\mathrm{i}}$ in different muscle tissues was kept constant and independent of the temperature (Butler and Day 1993). The opposite was true for Arenicola marina, where $\mathrm{pH}_{\mathrm{i}}$ changed according to alphastat predictions, while $\mathrm{pH}_{\mathrm{e}}$ was kept constant (Sommer et al. 1996).

Long-term exposure of Sipunculus nudus to $0^{\circ} \mathrm{C}$ caused a decrease in $\mathrm{pH}_{\mathrm{i}}$. The drop in ventilatory activity led to an accumulation of $\mathrm{CO}_{2}$, most likely linked to the development of an intracellular respiratory acidosis. The production of opines, propionate and acetate from glycogen is accompanied by the 
production of protons (Pörtner 1987a). In contrast, the depletion of PLA utilises protons (Pörtner et al. 1984) and the depletion of PLA, ATP and ADP leads to an accumulation of $P_{i}$ which increases the non-bicarbonate buffer value (Pörtner 1989). Hydrolysis of MgATP releases protons, but the amount is reduced by the dissociation of $\mathrm{Mg}^{2+}$ from $\mathrm{MgADP}$ as well as by the conversion of AMP to IMP (Pörtner 1987b). The net effect of these mechanisms, however, did not prevent proton accumulation. The depletion of the adenylates, the accumulation of phosphate and the acidosis led to a significant drop in the free-energy change of ATP hydrolysis, which represents the driving force for any ATPase reaction. A drop in $\mathrm{d} G / \mathrm{d} \xi$ below a critical level may cause severe disturbance of cellular functions and finally death. This might be one reason why animals were not able to recover after 4 days at $0{ }^{\circ} \mathrm{C}$, while after 2 days at $0{ }^{\circ} \mathrm{C}$ the change was not significant and animals recovered. If the change in $\mathrm{d} G / \mathrm{d} \xi$ is limiting survival then a level of $-52 \mathrm{~kJ} \mathrm{~mol}^{-1}$ (see Fig. 7) appears as the limiting level at $0^{\circ} \mathrm{C}$. However, little is known about the limiting levels of ATP free-energy change in marine invertebrates or their temperature dependence [for a more detailed discussion see Pörtner (1993)].

\section{Conclusions}

These results indicate that a low critical temperature exists between $4{ }^{\circ} \mathrm{C}$ and $0{ }^{\circ} \mathrm{C}$ for Sipunculus nudus dwelling in sediment. In its natural environment of the intertidal zone of Brittany, Sipunculus nudus will hardly ever encounter temperatures this low, since this species lives close to the low water line and mean water temperature is $9{ }^{\circ} \mathrm{C}$ in January and February (Isemer and Hasse 1985). The low critical temperature is characterized by the onset of anaerobic metabolism as indicated by the accumulation of acetate, propionate and succinate and by the development of acidosis which is not only related to metabolism, but also to respiratory acidification. In support of our present findings, a low and a high critical temperature were correlated with the onset of anaerobic metabolism in Arenicola marina (Sommer et al. 1996). In Sipunculus nudus the low critical temperature is explained by the drop in ventilatory activity seen below $4{ }^{\circ} \mathrm{C}$. Recovery from cold-induced anaerobiosis is only possible when cold exposure occurs during a limited time period. The "point of no return" is characterized by a decrease in the free-energy change of ATP hydrolysis which may fall below a critical level thus impairing the maintenance of cellular functions at low temperatures. Temperature is also interpreted to influence the steady-state levels of the adenylates by favouring ATP catabolism at low temperatures still above the $T_{\mathrm{C}}$ when the mode of energy metabolism is still completely aerobic.
Acknowledgements This study was supported by grants from the Deutsche Forschungsgemeinschaft to H. O. Pörtner (Po 278). We thank T. Hirse for excellent technical assistance. AlfredWegener-Institut Publication No. 1132.

\section{References}

Baumfalk YA (1979) On the pumping activity of Arenicola marina. Neth J Sea Res 13: 422-427

Beis I, Newsholme EA (1975) The contents of adenine nucleotides, phosphagens and some glycolytic intermediates in resting muscles from vertebrates and invertebrates. Biochem J 152: 23-32

Bergmeyer HU, Bergmeyer J, Graßl M (eds) (1983-1986) Methods of enzymatic analysis. Verlag Chemie, Weinheim, 3. Aufl.

Butler PJ, Day N (1993) The relationship between intracellular $\mathrm{pH}$ and seasonal temperature in the brown trout Salmo trutta. J Exp Biol 177: 293-297

Grieshaber M, Kronig E, Koormann R (1978) A photometric estimation of phospho-L-arginine, arginine and octopine using homogeneous octopine dehydrogenase isoenzyme 2 from the squid Loligo vulgaris Lam. Hoppe-Seyler's Z Physiol Chem 359: $133-136$

Grieshaber M, Hardewig I, Kreutzer U, Pörtner HO (1994) Physiological and metabolic responses to hypoxia in invertebrates. Rev Physiol Biochem Pharmacol 125: 43-147

Hardewig I, Addink ADF, Grieshaber MK, Pörtner HO, Thillart $\mathrm{G}$ van den (1991) Metabolic rates at different oxygen levels determined by direct and indirect calorimetry in the oxyconformer Sipunculus nudus J Exp Biol 157: 143-160

Hardewig I, Pörtner HO, Grieshaber MK (1994) Interactions of anaerobic propionate formation and acid-base status in Arenicola marina: an analysis of propionyl-CoA carboxylase. Physiol Zool 67: 892-909

Hazel JR, Garlick WS, Sellner PA (1978) The effects of assay temperature upon the $\mathrm{pH}$ optima of enzymes from poikilotherms: a test of the imidazole alphastat hypothesis. J Comp Physiol B 123: 97-104

Howell BJ, Baumgardner FW, Bondi K, Rahn H (1970) Acid-base balance in cold-blooded vertebrates as a function of body temperature. Am J Physiol 218: 600-606

Isemer HJ, Hasse L (1985) The Bunker climate atlas of the North Atlanctic ocean, vol 1: Observations. Springer, Berlin Heidelberg New York Tokyo

Kristensen E (1983) Ventilation and oxygen uptake by three species of Nereis (Annelida: Polychaeta) II. Effects of temperature and salinity changes. Mar Ecol (Progr Ser) 12: 299-306

Loomis SH, Carpenter JF, Achordoguy TJ, Crowe JH, Branchini BR (1989) Cryoprotective capacity of end products of anaerobic metabolism. J Exp Zool 252: 9-15

Malan A, Wilson TL, Reeves RB (1976) Intracellular pH in coldblooded vertebrates as a function of body temperature. Respir Physiol 28: 29-47

Michaelidis B, Storey KB (1990) Interactions of temperature and $\mathrm{pH}$ on the regulatory properties of pyruvate kinase from organs of a marine mollusc. J Exp Mar Biol Ecol 140: 187-196

Murphy DJ (1977) Metabolic and tissue solute changes associated with changing in the freezing tolerance of the bivalve mollusc Modiolus demissus. J Exp Biol 69: 1-12

Newell RC, Pye VI (1970a) Seasonal changes in the effect of temperature on the oxygen consumption of the winkle Littorina littorea (L.) and the mussel Mytilus edulis L. Comp Biochem Physiol 34: 367-383

Newell RC, Pye V (1970b) The influence of thermal acclimation on the relation between oxygen consumption and temperature in Littorina littorea (L.) and Mytilus edulis L. Comp Biochem Physiol 34: 385-397

Pette D, Reichmann H (1982) A method for quantitative extraction of enzymes and metabolites from tissue samples in the milligram range. J Histochem Cytochem 30: 401-402 
Pörtner HO (1982) Biochemische und physiologische Anpassungen an das Leben im marinen Sediment: Untersuchungen am Spritzwurm Sipunculus nudus L. Dissertation, Düsseldorf

Pörtner HO (1987a) Contributions of anaerobic metabolism to $\mathrm{pH}$ regulation in animal tissues: theory. J Exp Biol 131: 69-87

Pörtner HO (1987b) Anaerobic metabolism and changes in acidbase status: quantitative interrelationships and $\mathrm{pH}$ regulation in the marine worm Sipunculus nudus. J Exp Biol 131: 89-105

Pörtner HO (1989) The importance of metabolism in acid-base regulation and acid-base methodology. Can $\mathbf{J}$ Zool 67: 3005-3017

Pörtner HO (1990) Determination of intracellular buffer values after metabolic inhibition by fluoride and nitrilotriacetic acid. Respir Physiol 81: 275-288

Pörtner HO (1993) Multicompartmental analyses of acid-base and metabolic homeostasis during anaerobiosis: invertebrate and lower vertebrate examples. In: Hochachka PW et al. (eds.) Surviving hypoxia: mechanisms of control and adaption. CRC Press, Boca Raton, pp 139-156

Pörtner HO, Kreutzer U, Siegmund B, Heisler N, Grieshaber MK (1984) Metabolic adaptation of the intertidal worm Sipunculus nudus to functional and environmental hypoxia. Mar Biol 79: 237-247

Pörtner HO, Heisler N, Grieshaber MK (1985) Oxygen consumption and mode of energy production in the intertidal worm Sipunculus nudus L.: definition and characterisation of the critical $P_{\mathrm{O}_{2}}$ for an oxyconformer. Respir Physiol 59: 361-377

Pörtner HO, Vogeler S, Grieshaber MK (1986) Recovery from anaerobiosis in the intertidal worm Sipunculus nudus: I. Restoration of aerobic, steady-state energy metabolism. J Exp Biol 122: $37-50$

Pörtner HO, Boutilier RG, Tang Y, Toews DP (1990) Determination of intracellular $\mathrm{pH}$ and $P_{\mathrm{CO}_{2}}$ after metabolic inhibition by fluoride and nitrilotriacetic acid. Respir Physiol 81: 255-274

Pörtner HO, Finke E, Lee PG (1996) Effective Gibb's free-energy change of ATP hydrolysis and metabolic correlates of intracellular $\mathrm{pH}$ in progressive fatique of squid (Lolliguncula brevis) mantle muscle. Am J Physiol (in press)
Prosser CL (1991) Temperature. In: Prosser CL (ed) Environmental and metabolic animal physiology. Wiley-Liss, New York, pp 109-165

Reeves RB (1972) An imidazole alphastat hypothesis for vertebrate acid-base regulation: tissue carbon dioxide content and body temperature in bullfrogs. Respir Physiol 14: 219-236

Seymour MK (1972) Effects of temperature change on irrigation rate in Arenicola marina (L.). Comp Biochem Physiol 43A: 553-564

Siegmund B, Grieshaber MK (1983) Determination of mesoalanopine and D-strombine by high pressure liquid chromatography in extracts from marine invertebrates. Hoppe-Seyler's Z Physiol Chem 364: 807-812

Sommer A, Klein B, Pörtner HO (1996) Temperature-induced anaerobiosis in two populations of the polychaete worm Arenicola marina (L.). J Comp Physiol (in press)

Tekkanat KK, Fox IH (1988) Isocratic separation of ATP and its degradation products from biological fluids by automated liquid chromatography. Clin Chem 34: 925-932

Tewari YB, Goldberg RN, Advani JV (1991) Thermodynamics of the disproportionation of adenosine $5^{\prime}$-diphosphate to adenosine 5 '-triphosphate and adenosine 5'-monophosphate II. Experimental data, Biophys Chem 40: 263-276

Theede H (1972) Vergleichende ökologisch-physiologische Untersuchungen zur zellulären Kälteresistenz mariner Evertebraten. Mar Biol 15: 160-191

Trueman ER, Foster-Smith RL (1976) The mechanism of burrowing of Sipunculus nudus. J Zool 179: 373-386

Zandee DI, Kluytmans JH, Zurburg W, Pieters H (1980) Seasonal variations in biochemical composition of Mytilus edulis with reference to energy metabolism and gametogenesis. Neth J Sea Res 14: 1-29

Zebe E, Grieshaber M, Schöttler U (1980) Biotopbedingte und funktionsbedingte Anaerobiose. Biol Unserer Zeit 6: 175-182

Zuckerkandl E (1950) Coelomic pressures in Sipunculus nudus. Biol Bull (Woods Hole, Mass) 98: 161-173

Communicated by G. Heldmaier 